\author{
(D) Kutlay Aydın, \\ (1) Begüm Ergan, \\ (1) Murat Emre Tokur, \\ (1) Taner Calışkan, \\ (1) Gözde Gürsoy, \\ (1) Yusuf Savran, \\ (1) Erdem Yaka, \\ (1) Bilgin Cömert, \\ (1) Uğur Koca, \\ (1) Necati Gökmen
}

\section{Current Status of Organ Donation in a University Hospital in Izmir: Identifying Obstacles and Possible Future Solutions}

\author{
Izmir'de Bir Üniversite Hastanesindeki Organ \\ Donasyonunun Mevcut Durumu: Engellerin ve \\ Gelecekteki Olası Çözümlerin Belirlenmesi
}

Received/Geliș Tarihi : 29.11.2018

Accepted/Kabul Tarihi : 27.12.2018

${ }^{(}{ }^{\circ}$ Copyright 2019 by Turkish Society of Intensive Care Turkish Journal of Intensive Care published by Galenos Publishing House.
Kutlay Aydın, Begüm Ergan, Murat Emre Tokur, Taner Çalışkan, Yusuf Savran, Bilgin Cömert, Uğur Koca, Necati Gökmen

Dokuz Eylül University Faculty of Medicine, Intensive Care Unit, Izmir, Turkey

Erdem Yaka,

Dokuz Eylül University Faculty of Medicine,

Department of Neurology, Izmir, Turkey

Gözde Gürsoy,

Dokuz Eylül University Faculty of Medicine,

Department of Anesthesiology and Reanimation,

Izmir, Turkey

Kutlay Aydin (四),

Dokuz Eylül University Faculty of Medicine, Intensive Care Unit, Izmir, Turkey

E-mail : kutlayaydin@hotmail.com

Phone : : +90 5322649294

ORCID ID : orcid.org/0000-0003-2469-2833
ABSTRACT Objective: Although many new interventions including changes in diagnostic policies are performed to increase the rates of diagnosis of brain death (BD) and organ donation in recent years in Turkey, data about the longitudinal effects are limited. The aim of this study was to understand the current status of organ donation in Izmir and to find out whether new regulations have any effect on the diagnosis of $\mathrm{BD}$ and organ donation rates.

Materials and Methods: All patients diagnosed with BD between January 2001 and December 2016 in a tertiary university hospital were included, and patient data and organ donation status were collected from medical records.

Results: There were 303 patients diagnosed with BD during the study period. The most common reason in the pediatric group $(n=42)$ was traumatic brain injury $(42.9 \%)$ and 12 of these patients (28.6\%) became organ donors. In the adult patient group ( $n=261)$, the most common reason was intracranial hemorrhage (39.8\%) and 97 patients $(37.2 \%)$ became organ donors. The rate of BD diagnosis increased over the years (from $0.59 \%$ to $0.67 \%$ after legal regulation), but there was no increase in organ donation rate (39.5 vs $26.5 \%)$. The most common cause of ineligibility for donation was refusal by patient's relatives in both pediatric and adult patients $(83.3 \%$ and $86.6 \%$ respectively).

Conclusion: This study shows that although the diagnosis of BD has increased over the years, organ donation rates are still low in Izmir. New strategies aiming to increase awareness and change the perception of organ donation should be planned as soon as possible.

Keywords: Organ donation, brain death, refusal

ÖZ Amaç: Türkiye'de son yıllarda beyin ölümü teşhisi ve organ bağışını artıımak amacıyla teşhis yöntemlerindeki değişiklikleri de kapsayan pek çok yeni uygulama yapılmasına rağmen bunların etkileri ile ilgili bilgilerimiz sınırıdır. Bu çalışmanın amacı Izmir'de organ bağışının mevcut durumunu anlamak ve yeni düzenlemelerin beyin ölümü teşhisi ve organ bağışı üzerinde herhangi bir etkisi olup olmadığını öğrenmektir.

Gereç ve Yöntem: Bir üçüncü basamak üniversite hastanesinde Ocak 2001 ve Aralık 2016 arasındaki beyin ölümü teşhisi konan tüm hastalar, hasta verileri, organ nakli durumu tıbbi kayıtlardan elde edildi.

Bulgular: Çalışma süresince beyin ölümü teşhisi konan 303 hasta mevcuttu. Pediatrik grupta $(n=42)$ en çok görülen teşhis travmatik beyin hasarıydı $(\% 42,9)$. Bu hastalardan 12 hasta $(\% 28,6)$ donör oldu. Yetişkin hasta grubunda $(n=261)$ en sık görülen teşhis intrakraniyal kanamaydı $(\% 39,8)$ ve 97 hasta $(\% 37,2)$ donör olmuştu. beyin ölümü teşhis hızı yıllar içerisinde artmıştı (yasal düzenlemeden sonra \% 0,59'dan \%0,67'ye yükselmişti), ancak organ nakil hızında artış yoktu (düzenlemeden önce $\% 39,5$, düzenlemeden sonra \%26,5). Organ nakli yapılamamasının en sık görülen sebebi hem pediatrik, hem de yetişkin hasta grubunda hasta yakını reddiydi (pediatrik \%83,3, yetişkin \%86,6). Sonuç: Çalışma Izmir'de beyin ölümü teşhisinin yıllar içerisinde artmasına rağmen organ naklinin hala düşük kaldığını göstermektedir. Farkındalığı arttıracak ve organ nakline bakışı değiştirecek yeni stratejiler en kısa zamanda planlanmalıdır.

Anahtar Kelimeler: Organ bağışı, beyin ölümü, hasta yakını reddi 


\section{Introduction}

Although treatment options and technology in healthcare are growing exponentially, transplantation is still the main solution for organ failures. The disparity between the number of required organs for transplantation and the number of donor organs continues to be an important problem in many countries. Some countries such as Spain made comprehensive approaches with successful results and optimized performance in deceased donation, leading the country to an activity of 32-35 donors per million population $(1,2)$. But these programs are still very limited to few countries in Europe.

Turkey is one of the countries with serious problems in organ donation. In 2017, around 25000 patients are in the waiting list for organ donation. However, amongst 12,000 patients diagnosed between 2011-2017 years as brain death (BD) only $25 \%$ had organ donation (3). The current legal regulation for $\mathrm{BD}$ and organ donation in Turkey was published in February 2012 and revised in January $2014(4,5)$. The revision consisted of decreasing the need of four physicians (anesthesiologist, neurologist, neurosurgeon and cardiologist) to two (a neurologist or a neurosurgeon, and an anesthesiologist or an intensivist) to prevent delays in the diagnosis of BD. In addition to that, the Ministry of Health in Turkey started a project together with European Union (EU) which is aimed to develop quality and safety standards for human organ donation and transplantation, to harmonize of the EU acquis communautaire in the area cadaveric organ donation, to strengthen database structure and to increase donation rates (6). Other than those, Ministry of Health initiated an awareness campaign throughout the country in order to increase organ donation (7). The campaign consisted of information for not only the importance of organ donation but also religious perspective through media (television, radio and other social media channels) and in-hospital transplantation team services.

Although the aim of all these policies is to increase awareness and therefore the rates of diagnosis of $B D$ and organ donation, the longitudinal effects are not very well known. The objective of this study is to understand the current status of organ donation at a University Hospital in Izmir and find out whether these new regulations have any impact on $\mathrm{BD}$ diagnosis and organ donation rates.

\section{Materials and Methods}

Study population: The study was approved by Dokuz Eylul University Local Ethics Committee (protocol number: 2017/04-19) and conducted in a tertiary reference university hospital with 73 intensive care unit (ICU) beds. All adult and pediatric patients diagnosed with BD between January 2001 and December 2016 were included into the study. Data from medical records and hospital database were collected retrospectively. Patient demographics (age, gender), reasons for hospitalization, physical examination findings, tests performed for confirmation of BD transcranial doppler (TCD), computed tomographic angiography (CTA), electroencephalography (EEG), single photon emission computed tomography (SPECT), cerebral scintigraphy, the final status for organ donation, reasons for ineligibility for organ donation (medical problems, patients relatives refusal and other reasons) were recorded. Patients were grouped according to age: pediatric group ( $<18$ years) and adult group ( $\geq 18$ years)

The diagnosis of BD: The diagnostic criteria for BD was same throughout the study period: Clinical evaluation of $B D$ was performed in the presence of a severe structural brain lesion, a Glasgow Coma Scale score of 3/15, and absence of brainstem reflexes in normothermic patients according to current legal regulations made by Ministry of Healt in Turkey (8). Ancillary methods were used in some patients for confirmation of $\mathrm{BD}$ according to neurological evaluation. The study period was divided into two parts because of change in the criteria for the diagnosis of BD. According to regulatory laws for BD and organ donation in Turkey, the diagnosis of $\mathrm{BD}$ was made by a team of four physicians (anesthesiologist, neurologist, cardiologist and neurosurgeon) between January 2001 to December 2013 (Period 1). From January 2014, the diagnosis of BD was made by a team of two physicians (neurologist/neurosurgeon and anesthesiologist/intensivist) (Period 2). In order to understand the impact of regulatory change, we compared the rates of $\mathrm{BD}$ and organ donation for both periods.

\section{Statistical Analysis}

We conducted a retrospective cohort study and reported its results in accordance with the Strengthening the Reporting of Observational Studies in Epidemiology guidelines (9). The primary outcome of the study was whether the rate of $\mathrm{BD}$ diagnosis changed within years and new regulations made any impact on the diagnosis and organ 
donation. All categorical variables are expressed as numbers and percentages and continuous variables are expressed as mean and standard deviation (SD).

Chi-square or Fisher's exact tests were used to compare categorical variables between groups; Student's t-test or Mann-Whitney $U$ test were used to campare continuous variables. A two-tailed $p$ value of $<0.05$ was considered statistically significant. SPSS was used for statistical analysis (SPSS Version 20; IBM Corporation, Armonk, NY, USA) program.

\section{Results}

During study period, 303 patients were diagnosed with BD; $42(13.9 \%)$ of them were in pediatric group, whereas $261(86.1 \%)$ patients were in adult group (Figure 1).

Pediatric patients: The mean \pm SD age was $9.7 \pm 6.1$ years and $26(61.9 \%)$ were male. The most common reason for BD was traumatic brain injury (42.9\%) followed by anoxic brain injury (14.3\%) (Table 1). The apnea test was positive in 38 patients $(90.5 \%)$ and 4 patients' data is unavailable $(9.5 \%)$. Eighteen patients had the diagnosis of BD with clinical evaluation only. An ancillary test was performed in the rest of patients ( $n=24,57.9 \%$ ) and the most commonly used ancillary method in this age group was EEG $(41.7 \%)$ (Table 2).

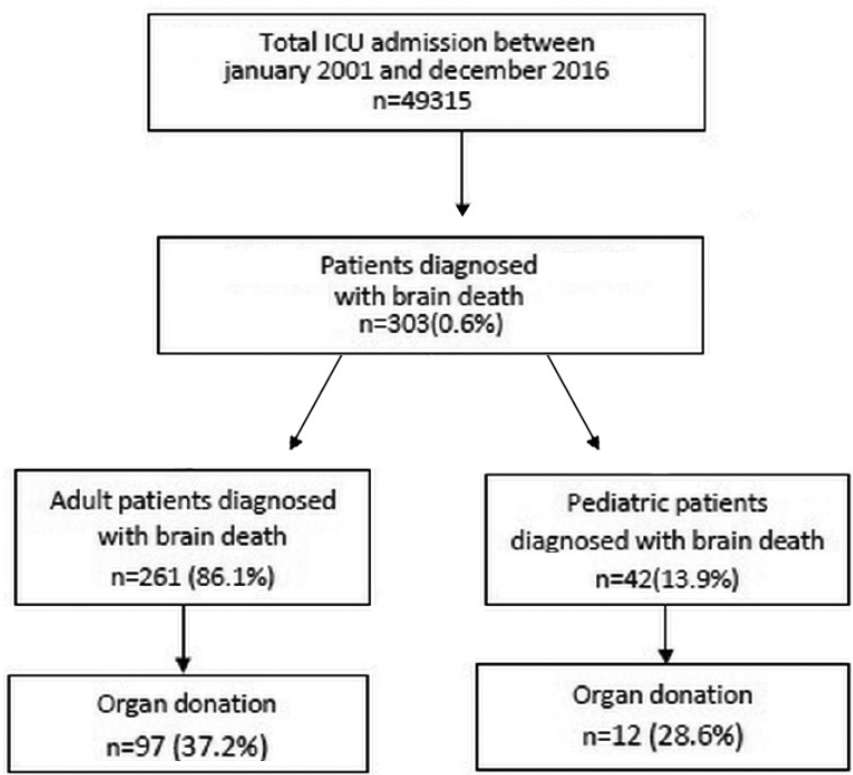

Figure 1. Study flow chart and distribution of patients according to age groups

ICU: Intensive care units
Twelve patients $(28.6 \%)$ were organ donors and the rest of patients $(n=30,71.4 \%)$ were not eligible for organ donation. The most common cause of ineligibility for donation was refusal of parents/patient's relatives $(n=25$; 83.3\%) (Table 3).

Adult patients: In adult patients the mean \pm SD age was $47.6 \pm 18.3$ years and 169 (64.8\%) were male. The most common reason for BD was intracranial hemorrhage (39.8\%) followed by traumatic brain injury (19.2\%) and ischemic stroke (15.3\%) (Table 1). The apnea test was positive in 217 patients (83.1\%) and couldn't be completed in 44 patients $(16.8 \%$ ) (in these patients, TCD was used in 8, CTA was used in 9 as an ancillary method. Other 27 patients' data is unavailable). TCD and CTA were the most commonly used

\begin{tabular}{|c|c|c|c|}
\hline & & $\begin{array}{l}\text { Adult group } \\
\text { ( } \geq 18 \text { years) }\end{array}$ & $\begin{array}{l}\text { Pediatric group } \\
\text { (<18 years) }\end{array}$ \\
\hline \multicolumn{2}{|l|}{$\mathrm{N}$} & 261 & 42 \\
\hline \multicolumn{2}{|c|}{ Age (years) } & $47.6 \pm 18.3$ & $9.7 \pm 6.1$ \\
\hline \multirow[t]{2}{*}{ Sex } & Male & $169(64.8)$ & $26(61.9)$ \\
\hline & Female & $92(35.2)$ & $16(38.1)$ \\
\hline \multicolumn{2}{|c|}{ GCS (at ICU admission) } & $3.5 \pm 1.4$ & $3.1 \pm 0.4$ \\
\hline \multicolumn{2}{|c|}{$\begin{array}{l}\text { Duration of ICU admission to } \\
\text { BD diagnosis (days) }\end{array}$} & $6.4 \pm 4.1$ & $5.8 \pm 5.1$ \\
\hline \multicolumn{2}{|c|}{ Hospital length of stay (days) } & $10.1 \pm 8.7$ & $11.9 \pm 7.9$ \\
\hline \multicolumn{2}{|c|}{ ICU length of stay (days) } & $7.3 \pm 5.1$ & $9.1 \pm 6.2$ \\
\hline \multicolumn{2}{|c|}{ Etiology of BD } & & \\
\hline \multicolumn{2}{|c|}{ Intracranial hemorrhage \# } & $104(39.8)$ & $3(7.1)$ \\
\hline \multicolumn{2}{|c|}{ Traumatic brain injury } & $50(19.2)$ & $18(42.9)$ \\
\hline \multicolumn{2}{|c|}{ Ischemic stroke } & $40(15.3)$ & $3(7.1)$ \\
\hline \multicolumn{2}{|c|}{ Anoxic brain injury } & $17(6.5)$ & $6(14.3)$ \\
\hline \multicolumn{2}{|c|}{ Intracranial mass* } & $14(5.4)$ & $3(7.1)$ \\
\hline \multicolumn{2}{|c|}{ Multiple trauma } & $11(4.2)$ & $3(7.1)$ \\
\hline \multicolumn{2}{|c|}{ Arteriovenous malformation } & $3(1.1)$ & - \\
\hline \multicolumn{2}{|c|}{ Other causes $¥$} & $22(8.4)$ & $6(14.3)$ \\
\hline \multicolumn{4}{|c|}{$\begin{array}{l}\text { Categorical variables are expressed as } n(\%) \text { and continuous variables are } \\
\text { expressed as mean } \pm \text { SD. }\end{array}$} \\
\hline \multicolumn{4}{|c|}{ \#Intracranial hemorrhage group include all patients with intracerebral } \\
\hline \multicolumn{4}{|c|}{$\begin{array}{l}¥ \text { Intoxication ( } n=6) \text {, epilepsy }(n=3) \text {, meningitis }(n=3) \text {, acute renal failure }(n=2) \text {, } \\
\text { hemorrhagic shock }(n=1) \text {, viremia }(n=1) \text {, hepatic failure }(n=1) \text {, septic shock }(n=1) \text {, } \\
\text { duraplasty }(n=1) \text {, encephalitis }(n=1) \text {, pneumothorax }(n=1) \text {, cardiac failure }(n=1) \text {, } \\
\text { aspiration pneumonia }(n=1) \text {, stomach cancer }(n=1) \text {, retinoblastoma ( } n=1) \text {, venous } \\
\text { sinus thrombosis }(n=1) \text {, stabbing }(n=1) \text {, unknown }(n=1) \text {. }\end{array}$} \\
\hline
\end{tabular}


ancillary method (44.6 and $39.3 \%$ respectively), followed by SPECT (8.9\%) (Table 2).

Ninety-seven patients (37.2\%) were organ donors and 164 patients (62.8\%) were not eligible to organ donation. The most common cause for ineligibility for organ donation was refusal of patients' relatives (86.6\%) (Table 3).

The rate of $\mathrm{BD}$ diagnosis and organ donation within study years: The rate of diagnosis of $B D$ is increased throughout the study period but this increase was not accompanied by organ donation rates (Figure 2). During Period 1 (2001-2013), amongst patients admitted to ICU, the rates for BD diagnosis and organ donation were 0.59\% (220/36866) and $39.5 \%$ (86/220) respectively. During Period 2 (2014-2016), which is after the change in diagnostic approach, the rate of diagnosis for BD was increased to $0.67 \%(83 / 12447)$ but organ donation rate was 26.5\% (22/83) (Figure 3).

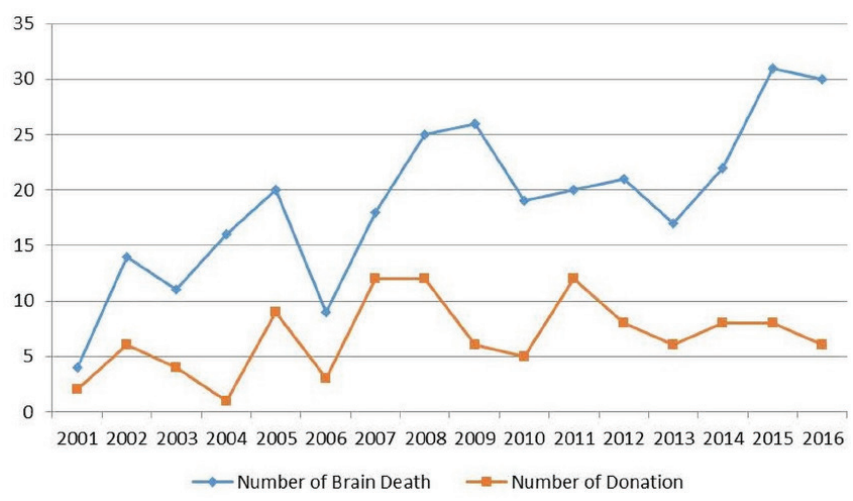

Figure 2. Annual numbers of patients for brain death and organ donation

\begin{tabular}{|l|l|l|}
\hline \multicolumn{3}{|l|}{ Table 2. Diagnostic approaches for brain death } \\
\hline & $\begin{array}{l}\text { Adult patient } \\
\text { group } \\
\mathrm{n}=261\end{array}$ & $\begin{array}{l}\text { Pediatric } \\
\text { patient group } \\
\mathrm{n}=42\end{array}$ \\
\hline Clinical diagnosis* & $149(57.1)$ & $18(42.1)$ \\
Positive apnea test & $217(83.1)$ & $38(90.5)$ \\
\hline Ancillary methods & $112(42.9)$ & $24(57.9)$ \\
TCD & $50(44.6)$ & $8(33.3)$ \\
CTA & $44(39.3)$ & $4(16.7)$ \\
EEG & $3(2.7)$ & $10(41.7)$ \\
SPECT & $10(8.9)$ & $1(4.2)$ \\
Cerebral scintigraphy & 5 (4.5) & 1 (4.2) \\
\hline $\begin{array}{l}\text { Data were presented as } n \text { (\%). } \\
\text { *Clinical diagnosis was established with presence of coma, complete loss of brain }\end{array}$ \\
stem reflexes and positive apnea test with confirmed after waiting time specified \\
for that age group (according to national guideline). \\
CTA: Computed tomographic angiography, EEG: Electroencephalography, SPECT: \\
Single photon emission computed tomography, TCD: Transcranial doppler \\
\hline
\end{tabular}

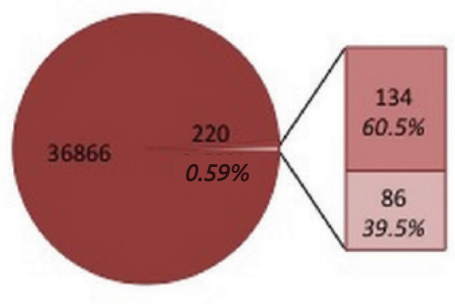

Period 1 (2001-2013)

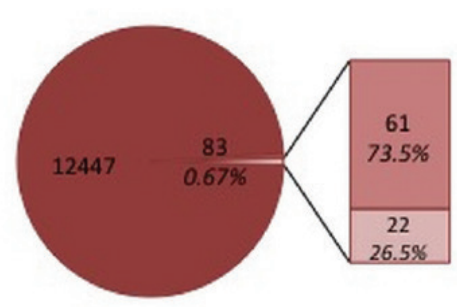

Period 2 (2014-2016)

$\begin{array}{ll}\text { ETotal ICU admissions } & \text { 口Organ donation-no } \\ \text { EPatients with brain death } & \text { 口Organ donation -yes }\end{array}$

Figure 3. Total number of patients admitted to intensive care unit, number of patients diagnosed with brain death (\%) and number of patients with organ donation (\%) for each study period

ICU: Intensive care unit

\begin{tabular}{|l|l|l|}
\hline $\begin{array}{l}\text { Table 3. Organ donation status in patients diagnosed with } \\
\text { brain death }\end{array}$ & $\begin{array}{l}\text { Adult } \\
\text { group } \\
\text { n=261 }\end{array}$ & $\begin{array}{l}\text { Pediatric } \\
\text { group } \\
\text { n=42 }\end{array}$ \\
\hline Yes & $97(37.2)$ & $12(28.6)$ \\
\hline No & $164(62.8)$ & $30(71.4)$ \\
\hline Reasons for ineligibility for organ donation & \\
\hline - Refusal of patient's relatives & $142(86.6)$ & $25(83.3)$ \\
- Ineligibility due to medical reasons & $7(4.3)$ & $1(3.3)$ \\
- Could not interviewed with patient & $5(3.0)$ & - \\
relatives & $10(6.1)$ & $4(13.3)$ \\
- Data unavailable & \multicolumn{2}{|l}{} \\
\hline Data were presented as n (\%) & \\
\hline
\end{tabular}

\section{Discussion}

The present study has two important results: First, the diagnosis of BD is increasing within years in our center, however this was not accompanied by organ donation rates. Second, the main reason for ineligibility for organ donation was refusal from patient relatives in both pediatric and adult age groups. 
Recently, Ministry of Health in Turkey declared important regulatory changes in order to increase organ transplantation rates. First, the reimbursements for the diagnosis of $B D$ and organ transplantation procedures are increased in order to encourage physicians. Second, the certification of BD was performed with two physicians after policy changes in 2014. These regulatory changes were expected to facilitate the rate of diagnosis of BD. In our study, although there is a huge variation between years, the number of diagnosis of $\mathrm{BD}$ is slowly increasing within time in our center. This finding is consistent with Ministry of Health data in which the number of BD diagnosis was increased from 1313 in 2011 to 2042 in 2017. Harmanci Seren and Yavuz (10) also reported that the number of the diagnosis of $B D$ increased nearly 5 times between 2005 and 2015 in Istanbul province and they commented that the increase is mainly due to increase in the number of transplant centers. Overall, the rate of $\mathrm{BD}$ diagnosis is increasing but it still is very low than expected as Turkey's population is more than 80 million. Currently, similar to Spanish model, transplant coordinators are actively working in many tertiary reference hospitals in Turkey however we think that further improvements are needed to have successful networking between transplant team and ICU physicians which is definitely a key step to enhance BD diagnosis. In addition interventions which aim to educate physicians and other health care personnel for assessment and determination of BD should continuously be reinforced.

In Turkey two clinicians with specific departments are required to diagnose BD. There is a huge variability of knowledge and practices for BD declaration among physicians despite there are clear algorithms for the diagnosis (11-13). It was reported that asynchrony between physicians may cause problems not only in the diagnosis of $\mathrm{BD}$ but also organ donation. It was previously reported that the difference in attitude of physicians might be an obstacle for BD diagnosis. A study of Kosieradzki et al. (14) showed that in Polish physicians difference in BD diagnosis procedure was considered as an important barrier especially in centers with low rates of organ donation. Varelas et al. (15) reported that BD certified with a single physician is easier, faster and more cost effective when compared to diagnosis with two physicians.

In this study, the overall organ donation rate was $37.2 \%$ in adults and $28.6 \%$ in the pediatric group, which is relatively lower than expected. Donor problem is still an important obstacle for organ transplantation in Turkey $(16,17)$. Deceased donation rates per million population was 5.1 which is much lower than European Countries $(16,17)$. According to 2017 data of Ministry of Health, only $26 \%$ of patients with BD proceeded to organ donation (3). We have found that, family refusal seems to be the main obstacle for organ donation and refusal rate is much higher than previously reported. This finding is contrary to other countries data in which the most common reason for ineligibility for organ donation was medical problems (17-20). Matesanz et al. (2) reported that the donation rate in Spain between 1999 and 2008 was between 50 to $60 \%$, and main obstacle in organ donation was due to medical contraindications whereas refusal from relatives was reported around $10-15 \%$. Similar to that, in a study performed in 42 Spanish centers, Escudero et al. (18) reported overall family refusal rate as $13 \%$. We think that the refusal of patient's relatives for organ donation needs specific attention, as there was no much change throughout the study years. Although, there are many programs conducted by Ministry of Health, more effective comprehensive interventions for sustainability of deceased donor should be planned according to national needs (21). Moreover, we think that socio-cultural and religious characteristics of the country should be taken into account in order to establish successful organ donation models. Certain profession groups, such as health care professionals, teachers, religion officers, which are role models and have influence for changing the behavior throughout the society should be targeted to achieve a snowball effect for improved attitudes towards donation (22). In a study performed in health care professionals it was shown that only a quarter of them owned a donation card, whereas this rate was found as low as $<1 \%$ in religion officers $(23,24)$.

When it is considered about family decision, If the family knows that the deceased person wants to be a donor, this affects positively the decision-making process. If the family does not know the deceased's wishes, this affects negatively the decision-making process. The other important factor is giving to the family sufficient time during the process. The families need time to make a decision. Another important factor is the dissatisfaction with the healt care system and this affects negatively the family during this process. If the family don't know sufficient information about the BD, this affects negatively the process. Health care professionals should be continuously trained about organ donation process (25). 
Patient's relatives expressed that they did not have enough information about donation process in Turkey. The ratio of organ donation from deceased donor is still low. Sufficient resources, research, and education should be planned increasing organ donation from deceased donor (26).

The study has limitations. First, the study was a retrospective study performed in a tertiary center therefore we think that our results may not be generalizable. Second, because of the retrospective nature of the study, detailed reasons for family refusals for organ donation is unknown. Third, we could not be able to analyze whether new policy for the diagnosis of BD shorten the time needed for the diagnosis. However the present study have important strengths. First it gives a perspective about the trends for the last 16 years of $\mathrm{BD}$ and organ donation in our Institution (in Turkey). Second we had the opportunity to better understand the effect of recent change in policy for the diagnosis of BD. Finally we think that our study gives important insights for the main obstacles and possible future solutions for organ donation.

\section{Conclusion}

Our study confirms that although changes in policies resulted to a positive impact to rate of $\mathrm{BD}$ diagnosis, this was not accompanied by organ donation in Izmir. New strategies which aim to increase population awareness and change in perception for organ donation/transplantation should be planned as soon as possible. In addition, training of health care professionals for good, informative and crystal clear communications with patient relatives should be encouraged.

\section{Ethics}

Ethics Committee Approval: Approval was obtained from the Non-Interventional Research Ethics Committee of Dokuz Eylul University (approval no: 2017/04-19, 02.03.2017).

Informed Consent: Not requiered.

Peer-review: Externally and internally peer-reviewed.

\section{Authorship Contributions}

Concept: K.A., N.G., E.Y., Design: K.A., B.E., N.G., E.Y., Data Collection or Processing: K.A., B.E., M.E.T., T.Ç., G.G., Y.S., Analysis or Interpretation: K.A., B.E., N.G., E.Y., B.C., U.K., Literature Search: K.A., B.E., E.Y., N.G., Writing: K.A., B.E., E.Y., N.G.

Conflict of Interest: No conflict of interest was declared by the authors.

Financial Disclosure: The authors declared that this study received no financial support. 


\section{References}

1. de la Rosa G, Domínguez-Gil B, Matesanz $\mathrm{R}$, Ramón S, Alonso-Álvarez J, Araiz J, et al. Continuously evaluating performance in deceased donation: the Spanish quality assurance program. Am J Transplant 2012;12:2507-13.

2. Matesanz R, Domínguez-Gil B, Coll E, de la Rosa G, Marazuela R. Spanish experience as a leading country: what kind of measures were taken? Transpl Int 2011;24:333-43.

3. Turkish Ministry of Health, Department of Organ, Tissue Transplantation and Dialysis. Last accessed date: 2 January 2018. https://organ. saglik.gov.tr/0TR/70lstatistik/ OrganNakillstatistikKamusal.aspx

4. Organ ve doku nakli hizmetleri yönetmeliği. Resmi Gazete: 01.02.201228191. Last accessed date: 14 June 2017. https://organ.saglik.gov.tr/ icerikler/DosyaYoneticisi/Belgeler/ Mevzuat/03GENELGE/GENELGE_ TODS_OrganNakilMerkezleri_2017_05. pdf

5. Sağlık Bakanlığı ve bağlı kuruluşlarının teşkilat ve görevleri hakkında kanun hükmünde kararname ile bazı kanunlarda değişiklik yapılmasına dair kanun. Kanun No. 6514. Kabul tarihi: 02/01/2014. Last accessed date: 14 June 2017. http://www.resmigazete.gov.tr/ eskiler/2014/01/20140118-1.htm

6. Technical Assistance For Alignment In Organ Donation Project. Last accessed date: 5 January 2018. http:// organdonationproject.com/index.php

7. Aykas A, Uslu A, Şimsek C. Mass media, online social network and organ donation: old mistakes and new perspectives. Transplant Proc 47:1070-2.

8. Turkish Neurological Society Diagnostic Guidelines for BD. Turkish Journal of Neurology 2014:20;101-4.

9. von Elm E, Altman DG, Egger M, Pocock SJ, Gøtzsche PC, Vandenbroucke JP.
The Strengthening the Reporting of Observational Studies in Epidemiology (STROBE) statement: guidelines for reporting observational studies. J Clin Epidemiol 2008;61:344-9.

10. Harmanci Seren AK, Yavuz H. Numbers of Brain Deaths and Deceased Donors in Hospitals in Istanbul Region That Have Transplantation Units: A Retrospective Analysis Between the Years 2005 and 2015. Transplant Proc 2017:49:392-5.

11. Pandey A, Sahota P, Nattanmai P, Newey CR. Variability in diagnosing BD at an academic medical center. Neuroscience J 2017;6017958:7.

12. Ghoshal S, Greer DM. Why is diagnosing brain death so confusing? Curr Opin Crit Care 2015;21:107-12.

13. Wahlster $S$, Wijdicks EF, Patel PV, Greer DM, Hemphill JC, Carone M, et al. Brain death declaration: Practices and perceptions worldwide. Neurology 2015;84:1870-9.

14. Kosieradzki M, Jakubowska-Winecka A, Feliksiak M, Kawalec I, Zawilinska E, Danielewicz R, et al. Attitude of healthcare professionals: a major limiting factor in organ donation from brain-dead donors. J Transplant 2014;2014:296912.

15. Varelas PN, Rehman M, Abdelhak T, Patel A, Rai $V$, Barber $A$, et al. Single brain death examination is equivalent to dual brain death examinations. Neurocrit Care 2011;15:547-53.

16. European Commission Journalist Workshop on Organ Donation and Transplantation Recent Facts and Figures. 26 November 2014. Last accessed date: 2 January 2018. https://ec.europa.eu/ health/sites/health/files/blood_tissues_ organs/docs/ev_20141126_factsfigures_ en.pdf

17. Rudge $\mathrm{C}$, Matesanz R, Delmonico FL, Chapman J. International practices of organ donation. $\mathrm{Br} J$ Anaesth 2012;108(Suppl 1):i48-55.

18. Escudero $\mathrm{D}$, Valentín $\mathrm{MO}$, Escalante JL, Sanmartín A, Perez-Basterrechea M, de Gea J, et al. Intensive care practices in brain death diagnosis and organ donation. Anaesthesia 2015;70:1130-9.

19. Cheung $C Y$, Pong ML, Au Yeung SF, Chau KF. Factors affecting the deceased organ donation rate in the Chinese community: an audit of hospital medical records in Hong Kong. Hong Kong Med J 2016;22:570-5

20. Mahdavi-Mazdeh M, Khodadadi A, Tirgar N, Riazi N. Rate of family refusal of organ donation in dead-brain donors: the Iranian tissue bank experience. Int J Organ Transplant Med 2013;4:72-6.

21. Delmonico $\mathrm{FL}$, Domínguez-Gil B, Matesanz R, Noel L. A call for government accountability to achieve national self-sufficiency in organ donation and transplantation. Lancet 2011;378:1414-8.

22. Frutos MA, Blanca MJ, Ruiz P, Mansilla JJ, Seller G. Multifactorial snowball effect in the reduction of refusals for organ procurement. Transplant Proc 2005;37:3646-8.

23. Erdoğan $O$, Yücetin $L$, Tuncer $M$, Keçecioğlu N, Gürkan A, Akaydin M, et al. Attitudes and knowledge of Turkish physicians about organ donation and transplantation. Transplant Proc 2002;34:2007-8.

24. Keten HS, Keten $D$, Ucer $H$, Cerit $M$, Isik O, Miniksar $\mathrm{OH}$, et al. Knowledge, attitudes, and behaviors of mosque imams regarding organ donation. Ann Transplant 2014;19:598-603.

25. Can F, Hovardaoglu S. Organ Donation: A Comparison of Donating and Nondonating Families in Turkey. Transplant Proc 2017;49:1969-74.

26. Kahveci B, Topal K, Gereklioglu Ç, Aksoy H. Attitudes Toward Organ Donation Among Relatives of the Patients Who Are Being Followed Up in Intensive Care and Dialysis Units. Transplant Proc 2017;49:1988-92. 